\title{
Certificate Completion And Compliance (CCC) For Building Certification In Malaysia: Literature Review
}

\author{
R. Zakaria ${ }^{1}$, A.I.C. Ani ${ }^{2}$, A.S. Ali $^{3}$ \\ 1,2 Department of Architecture, Faculty of Engineering and Built Environment, Universiti Kebangsaan \\ Malaysia, Bangi, Selangor \\ ${ }^{3}$ Centre for Construction, Building and Urban Studies, Faculty of Built Environment, University of \\ Malaya, Kuala Lumpur
}

\begin{abstract}
Certification of buildings is one of the conditions set by the government to ensure that buildings are constructed to achieve the required standards. This intended to safeguard the interests of the parties involved, especially the buyers. To improve public service delivery while not ignoring the interests of those involved, government held a new system for new building to obtain theirbuilding certification. The new system used calledCertificateCompletion and Compliance (CCC) where the appointed professionals were commonly known as Prinsiple Submitting Person (PSP), which will issue the certificate of the building. This study is to look at the existing literature related to building certification using PSP services under this CCC method. Literature from both local and overseas were revied in this paper. The authors intend to collect data from respondentsthat is the architects of 337 people and covers 12 local authorities in Selangor (first developed state in Malaysia). All types of buildings involved in this study. This study uses quantitative methods and qualitative questionnaires through interviews with respondents. All data were analysed by descriptive and inferential statisticsapproach.
\end{abstract}

\section{Introduction}

Building control is a process in which the buildings had been constructed and implemented in compliance with the provisions of by law specified. Through the control of the early stages of a building construction project is expected to avoid problems such as damage to buildings, sewers, safety, comfort and environment [1]. Building control is also a system to ensure that the design and construction of new buildings and additions of existing building space, renovation of existing buildings or the transfer function is carry out in accordance with the national standards set such as in the Uniform Building By-Laws 1984. In the implementation of building control, basically it involves organisations, developers and work on site either before, during and after a project was initiated [2]. Local Authorities (LA) in their respective areas to enforce building control early in the development of a project, ie the stage when a Development Order (DO) and building approvals to be given on the buildings to be set up during production certificate stating that the building was eligible or may be occupied [3].

In the aspect of building control, building certification is one of the conditions set by the government to ensure that buildings are constructed to achieve the required standards. This is intended 
to safeguard the interests of the parties involved, especially the buyers. In Bangalore, the provisions of the National Building Code Of India, states that any building that does not have a building certification is considered to be illegal building and cannot be occupied. The strict enforcement of building control is inevitable phenomenon from time to time in India [4]. According to Jenna [5], building control that carried out by LA is to ensure that all building works must obtain certificates and this not only applied for new buildings but to all construction works in the event of any changes happenedto a building

\section{Building Certification and CCC Definition}

\subsection{Building Certification}

Saleh [6] defines building certification is a written document issued by the local authority stating that the building or facility in the state that can be occupied or used in compliance with the building code and public health. While Ralph [7] defines building certification is a document that states that the inspection has found the project was implemented in accordance with local building codes and other regulations. Thus the building can be occupied and used.

\subsection{CCC}

Under the Building Regulations, Market Alternatives and Allodial Policy, also defines a Certificate of Completion is a written certificate stating that the construction work has been completed and complied with the conditions stipulated in the permit granted [8]. This means that the building was rendered uninhabitable. MPSP [9] defined that the CCC is a certificate that verifies a building is safe and fit for occupation and this certificate will only be issued after construction complied with the provisions of the law, approved building plan and also the conditions set by local authorities in the approval of the building plan.

\section{Justification for building certification}

Table 1 shows the briefly overall literature justify the importance of building certification in building control and information relating thereto.

Table 1: Justification Interest In Building Certification Building Control

\begin{tabular}{|c|c|l|c|}
\hline Year & Reference & \multicolumn{1}{|c|}{ Building Certification Statement } & $\begin{array}{c}\text { Building Control } \\
\text { Justification }\end{array}$ \\
\hline 2008 & NAHB & $\begin{array}{l}\text { Success of a project is when it acquired verification and certification } \\
\text { (certificate) from the authorities. }\end{array}$ & By-law \\
\hline 2009 c & John & $\begin{array}{l}\text { Certification is necessary for each facility that is used in the building } \\
\text { is especially risky buildings such as schools, hospitals and so on. }\end{array}$ & Safety \\
\hline 2009 & Richard & $\begin{array}{l}\text { Satisfaction inhabit a building that is when it is safe and comfort to } \\
\text { be occupied. }\end{array}$ & $\begin{array}{c}\text { Safety and } \\
\text { Comfort }\end{array}$ \\
\hline 2009 & Dave & $\begin{array}{l}\text { The building has a certificate or certificate showing that they are } \\
\text { building a strong and high investment. }\end{array}$ & Safety \\
\hline 2010 & Malcolm & $\begin{array}{l}\text { Building certification issued to certify the building had to comply } \\
\text { with building codes and is safe for occupation. }\end{array}$ & By-law and safety \\
\hline 2010 & Jenna & $\begin{array}{l}\text { The permit holder must make application for final building } \\
\text { certificate (certificate) whether for new construction, building } \\
\text { addition or renovation of buildings }\end{array}$ & Compliance \\
\hline 2011 & Alison & $\begin{array}{l}\text { Building owners can only occupy or use the building was purchased, } \\
\text { after getting clearance certificate from the authorities. }\end{array}$ & By-law \\
\hline
\end{tabular}




\section{Building Certification under the CCC Method}

In New Zealand, under the Building Act 2004, states that building owners must make an application for the CCC. However, an agreement can be made between the owner of the building to the professionals (for the building) appointed for the CCC from the LA [10]. Dorian [11] stated that in Honolulu, the CCC method is a certification made by the building professional implemented due to lack of staff in the Division of Planning and Permits (PBT) in the city. According to Dorian again the professional services given enable local governments to save costs and manpower. Robbins [12] and Neuman [13] states that under the CCC method, the professionals who have been authorized to issue building certificate may allowed legal action against them should they fail to carry out that responsibility.

This assertion is supported by Lisberg [14] stating in the event PSP fail to meet its obligations in accordance with applicable rules and laws, the professionals appointed to return the license granted for the issuanceof building certificates. In Australia, Parramatta City Council, using the provisions of the Environmental Planning and Assessment Act 1979 and the Environmental Planning and Assessment Regulation 2000 states that anyone appointed as a PSP under rule CCC shall make inspections on projects undertaken by the truth approved development [15]. John [16] stated the CCC will be approved and issued by the Architect or Engineer after inspection to ensure that the construction work carried out has been completed and comply with the approved plan specifications.

According to Kale et al. [17] states that every architect who has been appointed to create a whole and complete examination of all stages of construction and corrections if there are any noncompliance before recommending or issuing building certificate (CCC). This supported by Kevin (1) stating that the architect responsible for ensuring that all contractors involved in the project complies with all building codes and laws that applied prior to building certification issuance. Both of these statements are supported by Joseph [18] for the production of the CCC, appointed professionals should ask the contractors to make all the adjustments on the construction work that does not comply with the conditions of approval may be issued before the CCC. Anthony and Gregory [19] stated that when CCC liable for architects, it can speed up the application process without having to wait for LA to make inspections on projects. Anthony and Gregory added that CCC method is able to improve self-regulation of the professionals appointed other than that this method can reduce the workload of local authorities.

For the avoid any doubt on the construction work carried out, the building owner may appoint a third party, Professional Architect or Professional Engineer to verify or certify the construction work. CCC basically done by Professional Architect or Professional Engineer is authentic and accepted [20]. Nuala and Gabriel [21] states that in implementing a project is not necessarily a Professional Architect or Professional Engineer who will issue the CCC but the appointment of the person shall be qualified, skilled and know about the whole project. Apart from Professional Architects and Engineers Professional, other professionals that can produce CCC is Quantity Surveyor and Building Surveyor but they must be registered with their respective professional organizations [21].

In Bengalaru and Mumbai, India, CCC shall be certified by an architect or engineer registered or Building Supervisor. With a certificate issued by the professionals, this allows the building owner enter or occupy the building [22]. In America, Patrick [23] states when all the construction work had been completed at the site, the contractor shall notify the Building Inspector (PBT) to examine the work of the CCC for production purposes. If a registered architect or engineer who made the inspection, the Building Inspector (PBT) shall receive the CCC issued by them and do not need to make further checks. Sidney [24] says that any project that is involved with government contracts whether local authorities, State or Federal Government are still need to comply with the format used by the government contract as requirements specification, change directions, schedules, efidavit and various guidelines and regulations apply.

Compliance to ensure the withdrawal of all CCC by Architect to be easier and smoother. John [25] noted that before an architect can issue the CCC, the Project Architect shall ensure that all repair work has been done according to the prescribed period of time and have been satisfied with the repair 
work carried out by the contractor. John further explains that to ensure the building could be handed over in good condition and can be used as intended design. This assertion is supported by Triant and Dennis [26] to the state before the CCC could be issued, the professionals involved should monitor and advise contractors who involved in compliance with local laws covering equipment and building materials used. Table 2 provides a comprehensive literature related methods in the CCC building certification.

Table 2: Literature CCC Method in Building Certification.

\begin{tabular}{|c|c|c|}
\hline Reference & Place & Method of CCC Statement \\
\hline $\begin{array}{c}\text { New Zealand } \\
\quad[10]\end{array}$ & $\begin{array}{l}\text { New } \\
\text { Zealand }\end{array}$ & $\begin{array}{l}\text { Building owners need to make an application for the CCC to make the } \\
\text { agreement between building owners with professional (in the building) } \\
\text { appointed. }\end{array}$ \\
\hline $\begin{array}{l}\text { Robbins [12] \& } \\
\text { Neuman [13] }\end{array}$ & - & $\begin{array}{l}\text { With the CCC method, the professionals who are authorized to issue building } \\
\text { certificate may be legal action against them should they fail to carry out that } \\
\text { responsibility. }\end{array}$ \\
\hline Dorian [11] & Honolulu & $\begin{array}{l}\text { Under the CCC method, recommendations made by the professional building } \\
\text { due to lack of staff and the local authority is able to reduce energy costs and } \\
\text { local authority staff. }\end{array}$ \\
\hline Lisberg [14] & - & $\begin{array}{l}\text { Any appointed professionals will return the license issuing certificates In the } \\
\text { event of failure of a building. }\end{array}$ \\
\hline Susan [15] & Australia & $\begin{array}{l}\text { The main certifying appointed under rule CCC shall make inspections in } \\
\text { accordance with the approved development consent. }\end{array}$ \\
\hline John [16] & - & $\begin{array}{l}\text { CCC will be approved and issued by the Architect or Engineer after making } \\
\text { sure the construction work performed is completed and approved specification. }\end{array}$ \\
\hline Kale et al. [17] & - & $\begin{array}{l}\text { Architects appointed to examine the totality of all the construction and } \\
\text { correction of non-compliance before the CCC issued. }\end{array}$ \\
\hline Kevin (1) & - & $\begin{array}{l}\text { Architects are responsible for ensuring that all contractors involved in building } \\
\text { codes and comply with the law by building certificate (CCC) is issued. }\end{array}$ \\
\hline Joseph [18] & - & $\begin{array}{l}\text { The professionals appointed shall require contractors involved to make } \\
\text { corrections on work that does not comply with the conditions of approval may } \\
\text { be issued before the CCC. }\end{array}$ \\
\hline $\begin{array}{l}\text { Anthony dan } \\
\text { Gregory [19] }\end{array}$ & - & $\begin{array}{l}\text { CCC method can speed up the application process and the CCC will improve } \\
\text { self-regulation as well appointed professionals can reduce the workload of local } \\
\text { authorities. }\end{array}$ \\
\hline $\begin{array}{l}\text { Nuala dan } \\
\text { Gabriel [21] }\end{array}$ & - & $\begin{array}{l}\text { In addition to the Professional Architect or Professional Engineer issuing CCC } \\
\text { are eligible professional lian do as Quantity Surveyor and Building Surveyor } \\
\text { with a condition of registering with the respective professional organizations. }\end{array}$ \\
\hline $\begin{array}{l}\text { Feng Liu et al. } \\
\quad[22]\end{array}$ & $\begin{array}{l}\text { Bengalaru } \\
\text { dan } \\
\text { Mumbai }\end{array}$ & $\begin{array}{l}\text { CCC shall be certified by an architect or engineer or registered Building } \\
\text { Supervisor to enable building owners to enter or occupy the building. }\end{array}$ \\
\hline Patrick [23] & Amerika & $\begin{array}{l}\text { In addition to Building Inspector (PBT), if a registered architect examine the } \\
\text { work of building the Building Inspector (PBT) shall receive the CCC issued by } \\
\text { them. }\end{array}$ \\
\hline Sidney [24] & - & $\begin{array}{l}\text { Any of the projects involved with government contracts whether local } \\
\text { authorities, the State or Federal Government to comply with various rules and } \\
\text { regulations that apply to ensure that the withdrawal of the CCC by the } \\
\text { Architect to be easier and smoother. }\end{array}$ \\
\hline John [25] & - & $\begin{array}{l}\text { Before CCC released, Project Architect shall ensure that all repair work is done } \\
\text { in accordance with the time period specified and are satisfied with the repairs } \\
\text { done by the contractor to ensure the buildings are delivered in good condition } \\
\text { and can be used. }\end{array}$ \\
\hline $\begin{array}{l}\text { Triant dan } \\
\text { Dennis [26] }\end{array}$ & - & $\begin{array}{l}\text { The professional shall monitor and advise contractors involved in compliance } \\
\text { with local laws covering equipment and building materials used. }\end{array}$ \\
\hline
\end{tabular}




\section{Building Certification In Malaysia}

Building certification is one of the branches of the building control where it is a document of certificate issued by the parties to confirm that a building constructed regardless of whether new, additional buildings or the like have been eligible to be used or occupied [2]. Referring to the provisions of section 70, the Street, Drainage and Building Act 1974 (Act 133) if a project is to be implemented, it must obtain prior approval from the DO authority of local authorities. After the DO is obtained, the developer will submit building plans to the local authorities for approval before any construction work undertaken construction site [27]. Finally, after all the on-site construction work was completed in accordance with the conditions of approval and the provisions of the law, then the developer must apply for a certificate of building certificates from local authorities to enable the purchaser or owner of the building to occupy the building. The above process is a process of building control that must be adhered to by the parties that want to execute a construction project to safeguard the interests of the buyer. This to ensure that the buyer not to purchase the building that is not perfect and does not comply with the rules and regulations

\section{Scope and Method of Study}

Selection of research area is the state as it is the first developed state in Malaysia recognized [28] and to evaluate the effectiveness of CCC services method in developed state. All categories of buildings involved in this study as there was no difference in the processes and procedures involved. CCC's are the same for all building categories. Forthe selection of respondents represented by the $\mathrm{CCC}$, the PSP as the executor of the CCC and local authority monitoring as CCC (2).

Research strategy used in this research is in the form of quantitative and qualitative methods. Quantitative methods to obtain feedback from respondents, while the qualitative confirmation of the feedback received through the distribution of questionnaires. Researchers used sampling of respondents because their total population considered large [29]. Besides, the researchers also used the mailing method because it is simple and appropriate as the number of respondents is large [30].

\section{Conclusion}

Through literature review carried out found that the building certification was important in terms of safety for future building occupants. A building that has been obtaining certification indicates that the building was fit for use and occupation. As such, the government in providing the best service besides protecting the interests of the public, the CCC method was introduced. All parties involved either directly or indirectly should know their role in providing the best service. This is because if there are those who ignore their responsibilities and building certificates issued without compliance with approval conditions can have adverse effects on quality and safety of building. The literature review also showed that foreign countries are also very concerned about certification of every building constructed. This can be seen when the action is on the PSP that fail to discharge their duties properly, including the action interesting issue certificates of building licenses granted. There was a significant difference between the responsibilities of the PSP in the countries that use the PSP (professionals) to issue building certificate. In essence the responsibility and role of the PSP is to regulate or ensure that a building has complied with all conditions of approval before they can issue the building certificate. The PSP also responsible to ensure that the contractor involved in a project to make repairs or corrections if there are conditions attached to non-compliance. After the repair or correction PSP must once again examine the work that has been carried out correctly. If the PSP was satisfied with the work, the compliance certificate for the building can then be issued. In this way the occupier or owner of the building got a quality building as well as their safety is more assured. However,to maintain the quality of their services, the PSP should always work ethics as a system of professional practice as well as good work. By keeping the two of these things can keep the PSP's performance in carrying out their responsibilities. 


\section{References}

1. Malaysia. 2007a. Akta Jalan, Parit Dan Bangunan 1974. (Akta 133).

2. Izyan, F. M. 2006. Kawalan Bangunan Dari Perspektif Pihak Berkuasa Tempatan. Tesis Sarjana Muda. Fal, Senibina, Perancangan Dan Ukur, Universiti Teknologi Mara.

3. Ireland. 2000. Ireland Building Regulations

4. India. 2005. National Building Code Of India.

5. Jenna, M. (2010). Building Permit Supplemental Instructions for Final Certificate. McGraw Hill.

6. Saleh, M. (2010). Construction project Scheduling and Control. John Wiley \& Sons Inc.

7. Ralph, W. L. (2008). Construction Of Architecture From Design To Built. Canada: John Wiley \& Sons Inc.

8. United State. 2003b. Building Regulations, Market Alternatives And Allodial Policy.

9. MPSP. 2007. Apakah Yang Dimaksudkan Dengan 'Perakuan Siap Dan Pematuhan?”, tahun 2007.

10. New Zealand. 2005. Building Officials Guide To The Building Act 2004. Department of Building and Housing

11. Dorian, D. (2007). Should Architects Self-Certify Building Plan?. New York: NY Daily News.

12. Robbins, T. (2005). Too Tall In Park Slope. New York: The Village Voice.

13. Neuman, W. (2006). Brooklyn:Architect Settles Charges. New York: The New York Times.

14. Lisberg, A. (2008). "Building Department To Crack Down On Outlaw Architects". New York: Daily New.

15. Susan, T. (2007). Planning Australia: An Overview Of Urban and Regional Planning. New York: Cambridge University Press.

16. John, W. R. (2000). The Language Of Real Estate. Ed. ke-5. Dearborn: Financial Publishing

17. Kale, C. M., Shah, M. G. \& Patski, S. Y. (2002). Building Drawing: With An Integrated Approach To Build Environment. Ed. ke-4. Bostan: Tata McGraw-Hill Publishing.

18. Joseph, A. D. (2008). The Architect's Handbook Of Professional Practice. Ed. ke-14. New Jersey: John Wiley \& Sons Inc.

19. Anthony, S. \& Gregory, S. (2004). Architect's Legal Handbook: The Law For Architects. Ed. ke8. United Kingdom: Elsevier Ltd.

20. John, J. P. (1993). Construction Contract Law. Canada: John Wiley \& Sons Inc.

21. Nuala, C \& Gabriel, B. (2008). Conveyancing (Law Society Of Ireland Manual). Ed. ke-4. United State: Oxford University Press.

22. Feng, L., Anke, S. M. \& John, F. H. (2010). Mainstreaming Building Energy Efficiency Codes In Developing Countries: Global Experiences And Lessons From Early Adopters. Washington: The World Bank.

23. Patrick, W. C. 1979. Research And Innovation In The Building Regulatory Process. Proceedings Of The Third Annual NBS/NCSBCS Joint Conference Held. hlm. 103-106.

24. Sidney, M. L. (2006). Project Management In Construction. Ed. ke-5. San Francisco: McGrawHill Companies Inc.

25. John, R. C. (2001). Architects, Engineers And The Law. Ed. ke-3. Sydney: The Federal Press.

26. Triant, G. F. \& Dennis, L. (2009). Managing Aviation Projects From Concept To Completion. Farnham Survey: Ashgate Publishing Ltd.

27. Malaysia. 2007b. Undang-undang Kecil Bangunan Seragam 1984. (P.W.5178/85).

28. UPEN (2005). Selangor Maju 2005: Konsep Yang Menjadi Realiti.

29. Sekaran, U. \& Bougie, R. (2010). Research Methods For Business: A Skill Building Approach. Edisi ke-5. New York: John Wiley \& Sons, Inc.

30. Sarantakos, S. (1988). Social Research. New York: Palgrave. 